\title{
Community Voices: Insights on Social and Human services from People with Lived Experiences of Homelessness
}

\author{
Christine Ann Walsh ${ }^{\mathrm{a}^{*}}$, Liza Lorenzetti ${ }^{\mathrm{b}}$, Natalie St-Denis ${ }^{\mathrm{c}}$, Percy Murwisi ${ }^{\mathrm{d}}$, Tracy Ray Lewis ${ }^{\mathrm{e}}$ \\ a Professor, Associate Dean (Research and Partnerships) Faculty of Social Work, University of Calgary \\ b Faculty of Social Work, University of Calgary \\ c Faculty of Social Work, University of Calgary \\ e \\ ${ }^{*}$ Corresponding author's email address: cwalsh@ucalgary.ca
}

\section{A R T I C LE IN F O}

Received: 03-09-2015

Accepted: 14-01-2016

Available online: 03-03-2016

\section{Keywords:}

\section{Homelessness;}

Human rights;

Participatory action research;

Services;

Social work.

JEL Classification:

I14; I38; Z18.

\section{A B S T R A C T}

Community Voices is a participatory action research study conducted in collaboration with people with lived experiences of homelessness in Calgary, Alberta to gather insights into service provision. Following convenience and snowball recruitment strategies, seven focus groups with members of the homeless community were conducted by trained facilitators. Participants and other community members were invited as coresearchers to analyze focus group transcripts, highlight key issues, develop themes and recommendations, and share key findings with stakeholders. Study findings suggest that people who are homeless experience oppression at the personal, cultural and structural levels which make it less likely for them to exit homelessness. Our findings suggests that a housing first approach coupled with intensive personalized case management embedded within a human rights framework has the capacity to reduce homelessness and overcome the barriers that prevent individuals from exiting homelessness. Such interventions, however, require substantial investment to increase the stock of affordable housing units, improve current shelter facilities, and educate personnel in anti-oppressive practices and a political commitment to recognize housing as a human right.

(C) 2016 The Authors. This is an open access article under the terms of the Creative Commons Attribution License 4.0, which allows use, distribution and reproduction in any medium, provided the original work is properly cited.

DOI: http://dx.doi.org/10.18533/rss.v1i2.7

An estimated 160,000 Canadians experience homelessness every year (Trypuc \& Robinson, 2009), although the exact prevalence is difficult to determine due to the challenges of definition and methodology (Begin, Casavant, Miller Chenier, \& Dupuis, 1999; Peressini, McDonald, \& Hulchanski, 1996). The Canadian Homelessness Research Network (2012) defines homelessness as:
... an individual or family without stable, permanent, appropriate housing, or the immediate prospect, means and ability of acquiring it. It is the result of systemic or societal barriers, a lack of affordable and appropriate housing, the individual/household's financial, mental, cognitive, behavioural or physical challenges, and/or racism and discrimination. Most people do not choose to be homeless, and the experience is generally negative, unpleasant, stressful and distressing. (p. 1)

Calgary has the largest homeless population in the province of Alberta, according to the most recent point-in-time homeless count in October 2014. This number, 3,531 people, similar to the count six months earlier, with 1,766 
people in emergency shelters, 1,292 in short-term supportive housing, 315 with no fixed address while in jail or hospital; and 158 "rough sleepers" residing on the streets (Calgary Homeless Foundation [CHF], 2014).

The Calgary 10 Year Plan to End Homelessness was created in 2008 by the CFH as a response to the growing rates of homelessness; their mandate states that "an individual or family will stay in an emergency shelter or sleep outside for not longer than a week before moving into a safe, decent, affordable home with the support needed to sustain it" (CHF, 2012a, p. 1). In order to reach this goal, the CHF provides funding to housing programs delivered by a number of agencies across the City, and also conducts and funds research to better understand trends and needs of homeless sub-populations (for example, women fleeing domestic violence) to inform and direct policy development and program design (CHF, 2012a).

The Plan employs a case management approach to house and support clients to maintain housing based on the housing first approach (CHF, 2012a). The housing first model is designed as a low barrier program to house the most vulnerable homeless people without prerequisites of good mental health, psychiatric treatment or sobriety. The objective of the housing first model is to stabilize people in homes and then appropriately address other associated issues. This approach arose from the limitations of the traditional continuum of care model, with the objective of effectively serving chronic and episodic homeless populations (Gulcur, Stefancic, Shinn, Tsemberis, \& Fischer, 2003). Recognizing the cost-effectiveness of providing permanent housing with supports to break the cycle of homelessness, the Plan exemplifies a paradigm shift from managing homelessness to ending it. Although the Plan does not eliminate the use of emergency shelters, the target standard is that a person will be without a home for a maximum of seven days before being housed and supported (CHF, 2012b).

In the Community Voices study, we used an exploratory qualitative research design with a participatory action research framework (MacDonald, 2012) to collaborate with people experiencing homelessness in Calgary in order to better understand their experiences of social and human services in the context of the Plan's implementation. People were also asked to suggest relevant recommendations regarding existing programs, services, and policies.

\subsection{Methodology}

The search for knowledge that is "information rich" (Patton, 2002, p. 230) guided our choice to adopt a qualitative research methodology with a participatory action research (PAR) framework. PAR asserts that experiential knowledge is a valid form of expertise (Altpeter, Schopler, Galinsky, \& Pennell, 1999) and that "given the proper tools, the people most affected by a problem are not only capable of better understanding their realities, but are also the best equipped to address their struggles" (Koirala-Azad \& Fuentes 2009/2010, p. 1). PAR aims to eliminate power differentials between professional researchers and community experts, and uses critical reflection that legitimizes personal and emotional experiences in the framing of knowledge (Fook \& Askeland, 2007), with the ultimate goal of influencing social change (Brydon-Miller, 1997). While traditional qualitative forms of data gathering (focus groups) were utilized in this research, persons with previous experiences of homelessness were involved in all phases of the study, including the initial design, the development of research questions, the recruitment of participants and co-researchers, the facilitation of focus groups, the analysis of data, and the creation of knowledge through report writing and dissemination. Additional co-researchers with lived experiences of homelessness participated in the analysis and dissemination phases of the study.

Convenience and snowball sampling techniques (Atkinson \& Flint, 2004), were used to invite people who had previous or current experiences of homelessness to participate in a series of focus groups to share their stories of accessing human and social services in Calgary. These individuals are described as study participants. Focus groups, which are carefully planned group discussions to explore a set of specific issues, with the goal to learn more about perceptions, feelings, attitudes and ideas (Chiu, 2008), have been found to be useful in generating practical knowledge about complex policy issues (Krueger \& Casey, 2000). Focus group facilitators received training on PAR and focus group methodology (Harding, 2013). Focus group discussions were framed by a field guide comprised of semi-structured, open ended questions designed to elicit lived experiences of participants and provide feedback into existing programs and services, and into policies at the municipal, provincial and/or federal levels.

The study received institutional ethics approval and individual participants and co-researchers (described below) provided written informed consent and basic demographic information. Focus groups were co-facilitated by members of the research team, at least one of whom had direct lived experience of homelessness.

Between October and November 2011, we completed seven focus groups with a total of 41 participants who had direct lived experiences of homelessness. Focus groups were audio-recorded, and transcribed verbatim. Transcripts were subsequently analyzed by research team members and co-researchers $(n=21)$. We use the term co-researchers to describe participants "as joint contributors and investigators to the findings of a research 
project... collaborators in the process of gathering and interpreting data" (Boylorn, 2008, p. 600). The aim of this analysis process was to enhance the trustworthiness of the findings (Williams, Unrau, \& Grinnell, 1998) through co-researcher involvement and to also deepen the research capabilities of the co-researchers. We conducted a full-day data analysis workshop, which began with introducing co-researchers to the study and providing them with a brief tutorial on qualitative data analysis techniques (Bryman \& Burgess, 1993). The focus group transcripts were thematically analyzed as follows: (1) Three co-researchers (a student research assistant, a person with lived experience of poverty and an experienced researcher) collaboratively reviewed one or two focus group transcripts, conducted open coding, assigning codes and code descriptors to each code; (2) In the second review, group members performed targeted coding; they collapsed, integrated and organized codes into themes and subthemes; (3) In the third review of the transcripts, co-researchers completed selective coding, selecting the core category in relation to other categories according to the objectives of the study. In this stage, they also identified quotes from the transcripts that illustrated the various themes and subthemes they had identified; (4) Each group then shared one or two of the major themes they had classified (with accompanying quotes) with the entire research team; (5) Members of the larger group provided feedback as either resonating with or differing from the various themes they had identified. When appropriate, enriched or alternative themes or interpretations were noted; (6) Finally, members of the entire research team developed preliminary recommendations based on the preliminary study findings. Hand-written notes were taken throughout the process, which became part of the dataset.

The research team then amalgamated all of the findings from the data analysis workshop, and further reviewed the findings to identify pathways, relationships and linkages between themes and subthemes. Preliminary recommendations were also further developed based on the findings of the data analysis followed by a targeted literature review of relevant literature.

To increase the trustworthiness of the findings (Shenton, 2004), we invited co-researchers to participate in a twohour validation workshop during which the findings were presented to the panel of co-researchers $(n=21)$ who were asked to provide additional feedback or suggest alternative considerations or interpretations. Again, handwritten notes were taken during this session and were added to the dataset. Subsequently, we shared study findings and recommendations in five key settings to targeted audiences which included: (1) service providers, activists, and people with lived experiences of homelessness, (2) the general public, (3) a national conference on homelessness; (4) local community leaders, and (5) local practitioners, researchers and policy makers. In each case, at least one presenter was a co-researcher with lived experience of homelessness. Participants at these events provided feedback and input on the themes and recommendations. Finally, we shared the findings with the Research Committee of the Provincial Interagency Council on Homelessness who agreed to take action, which is consistent with the requirement of the PAR process (Brydon-Miller, 1997).

\subsection{Results}

From the analytic process, we identified the following six themes: (1) Systemic oppression; (2) Multiple barriers in finding and maintaining employment; (3) Criminalization of homelessness; (4) Lack of accountability; (5) It's more than housing; and (6) Resilience in the face of adversity. Each of the major themes included a number of sub-themes. In the following section, we present a detailed description of each major theme and its associated subthemes along with illustrative quotes drawn from the dataset (transcripts, and written notes) and evidence abstracted from the literature. Although themes and sub-themes are reported as distinct for the purpose of this report, in the lives of homeless people, they played out in complex and interconnected ways.

\subsection{Themes 1: Systemic oppression}

Despite a person's unique experience of homelessness, participants' interactions with agencies and human resources deeply resonated with one another, creating a story of systemic oppression. Oppression, defined as the way in which a dominant group maintains its privilege and power by exploiting and denying other groups the same opportunities, is expressed through exclusion and discrimination, which prevent people in subordinate groups to fully participate in socioeconomic and sociocultural opportunities (Mullaly, 2010). Over a period of time, systemic oppression has significant and profound negative impacts on a person's emotional and physical health, which then further reduces a person's ability to fully participate in society (James et al., 2010). Oppressive forces identified in this study occurred on structural, cultural and individual levels, and contributed to entry into homelessness and the way in which supports and resources were offered to aid in exiting homelessness.

\subsubsection{Individual level oppression}


Oppression on this level arises from negative beliefs, attitudes and behaviours held by the dominant group towards the subordinate group, expressed through alienation, as well as conscious or unconscious acts of aversion and avoidance (Mullaly, 2010). Participants in the study described encountering consistent negative attitudes with some agencies appearing more interested in following procedures and protocols than providing effective services. As one participant explained, "There's a real belief out there that homeless people are scum. The politics in this province are: if you're poor and you're homeless it must be because you deserve it and something you did."

Homeless people in a New York study expressed similar sentiments, stating that outreach workers do "their jobs for financial reasons and that workers have little incentive to help end homelessness because they rely on the homeless population for employment" (Kydra \& Compton, 2009, p. 147).

Oppressive practices at the personal level lead homeless people to develop a mistrust of social and human services (Kydra \& Compton, 2009; Thompson, 2006), limiting a person's ability to exit homelessness. To remediate this, participants in this study concurred with other research, which advises front-line staff to spend "more time with each client, engaging and listening to the client, and expressing empathy" (Kydra \& Compton, 2009, p. 146).

\subsubsection{Cultural level oppression}

Oppression at the cultural level stems from the norms, values and ideals that reflect the dominant culture and are expressed through stereotypes, stigma and language that is repeated and perpetuated through mass media and dominant discourses (Mullaly, 2010). This form of oppression impacts the emotional wellbeing of those living in homelessness, and affects how they access supports (Shier, Jones, \& Graham, 2010). Study participants described feeling reluctant to using services:

It's not a shameful thing to ask for help but when you go in and ask for help and you feel degraded and made to feel you don't deserve their help you are not going to ask. After you have been raped, humiliated and degraded by the system you just go out and you just decide fuck it. Well when you are dealing with women and men who are knocking on doors they get degraded, they get pushed away, they get pushed aside they aren't going to ask for help anymore. They are going to maintain on the street and the street leads to crime. They have no place to go. It's easier.

\subsubsection{Systemic level oppression}

This form of oppression has been described as "the beginning point and end product of all other forms of oppression. It is the essential structure of society, the sum total of all the other inequalities" (Bishop, 2002, p. 82), and is expressed through inequalities in wealth, privilege and power between the rich, or upper class, and the working poor, or those stigmatized as "lower" class. In Canada, Calgary has the largest income gap between rich and poor, and Alberta has been identified as the province with the largest income inequalities (Parkland Institute, 2013).

Current services, representing structural barriers, are built to represent the dominant culture's ideas, values and expectations, which do not necessarily represent the needs and realities of the underprivileged, as one participant articulated:

It's like applying for housing and you are filling out the application form and they want your ID, your bank statements and birth certificate, and who your previous landlord was and your income taxes and your GST forms and references, and where you worked and your Social Insurance Number and a criminal record check. Well, if you've been on the streets for ten years, when was the last time you filed your income tax? You don't have a landlord and you don't have good references. So how are you supposed to access all these housing projects that are out there when you don't have the wherewithal to get through all of the screening?

\subsection{Theme 2: Barriers to employment}

Among homeless populations, barriers to employment significantly contribute to a diminished quality of life (Lam \& Rosenheck, 2000) and an inability to exit homelessness (Shier, Jones, \& Graham, 2012). Employment is a positive source of self-esteem and independence, as well as the primary means of re-integration or re-socialization into mainstream society (Blankertz, McKay, \& Robinson, 1998). Calgary's unemployment rate is low (4.9\%, or 2.1\% below the national average) (Statistics Canada, 2013) and the majority of homeless people in Calgary are employed (City of Calgary, 2008). However, participants in the study reported barriers to employment related to their homeless status including: lack of stable housing, access to technology and transportation, lack of knowledge about and access to employment services, and discrimination by employers.

3.2.1 Lack of stable housing and access to transportation and technology 
Living on the streets or in a shelter limits homeless persons from meeting their basic needs, such as hygiene, nutrition and quality of sleep (Shier, Jones, \& Graham, 2010). This, in turn, impacts their ability to search for and maintain employment, and contributes to feelings of shame associated with the disclosure of their homeless status. The negative association between shelter life and employment is described by one participant:

The biggest problem with being homeless is sleep deprivation. So you are sleeping with lights on all night. They wake you up at 5:00, you try to hold down a job let's say for example you are working 3:00 to 11:00 and you are getting absolutely no sleep. I had a job at [company name] but I was in that position where they placed me in a full time job, doing warehouse work at 48 years old, no experience doing warehouse work. Lifting 50, 60 pound boxes and I have high blood pressure and fibromyalgia. I wasn't getting my sleep, my boss was yelling at me all the time and I lost that job. Now I am back to square one again. I was like, even without looking for work, when you are sleep deprived, you have nowhere. In summer we sleep in the parks. You see it all the time people are falling asleep. The police come along and wake you up and tell you, you can't sleep there.

Next to housing, transportation is identified in the literature as the most significant barrier to employment (Sommers et al., 2005). Similar to recommendations in the literature to provide free bus passes (Munoz, Reichenbach, \& Hansen, 2005), one participant suggested:

There needs to be some sort of system when you're homeless that you could get a card so that you can ride on the transit and not get a transit fine. Without transit, you're limited to the areas that you can walk to. To give a homeless person a transit fine is absolutely ridiculous, because they're not going to be able to pay the fine and they end up having a warrant out for their arrest because they have unpaid transit fines.

Limited access to technology (computers, Internet and cell phones) also negatively impacts the ability of members of the homeless community to obtain and maintain employment (CHF, 2012b; Eyrich-Garg, 2011; Sommers et al., 2005). This was underscored in our study by one participant:

You're supposed to call 6 to 12 people a day to try to find a job. But if you have nowhere to live, and no phone number, and no computer access, yeah, you have this access [at the shelter], but there's a line up all the time. It's not like you can just walk right in and use the computer and get your things done.

\subsubsection{Lack of knowledge about and access to employment services}

Study participants expressed a limited understanding of the various employment-related services and supports. One participant depicted the entanglement of agency rules and mandates as prohibitive:

Each organization requires a referral. If you need some nice clothing for a job interview, you need to get a referral to get the clothes. But in order to get that referral, you need to get a referral for the referral.

The perception of inadequate employment-related services among homeless respondents led them to rely on the informal knowledge network, as one person suggested:

You don't know the different resources that are available until you get together with a group of people that are homeless and you learn more from them. There should be a way people are given the knowledge of what's out there.

Similar research in Vancouver highlights complex barriers engrained within employment services. For instance, Sommers et al., (2005) identified that in order to access employment services, clients had to be recipients of social assistance, which they found excluded the majority of homeless people.

\subsubsection{Discrimination by employers}

Discrimination by potential employers towards members of the homeless community significantly reduced their opportunities to obtain and maintain housing (CHF, 2012b). One participant shared his experience of being stigmatized as a consequence of his homelessness:

Employers are not looking for guys that are sleeping on a mattress. You are not reliable to them as soon as they hear you're homeless. The majority of the time it's like, we have other guys looking for work who own their own homes. Basically they make a stereotype: if you're in a homeless shelter then you're not a reliable worker. 
As documented in the literature, these negative experiences also decrease the confidence of people who are homeless to seek employment. Those who struggle with mental health issues are further discouraged by the fear of being discriminated against and being rejected (Ferguson et al., 2011; Lam \& Rosenheck, 2000).

\subsection{Theme 3: Accountability}

Despite the rhetoric surrounding individual responsibilities for homelessness, structural factors including the lack of safe, affordable housing, and a living wage, are the major contributors to homelessness (Kauppi \& Bradley, 2003). Hulchanski (2009) advocates for remedial action on the micro level (individuals and their families), the mezzo level (agencies, communities and municipalities), and macro level, (provincial and federal governments and social policies).

\subsubsection{Agency accountability}

Agencies serving those at-risk of homelessness need to guarantee the necessary supports, financial and emotional are available to maintain housing (Gaetz, 2010). Agencies also need to evaluate service effectiveness attending to broader systemic factors that pertain to homelessness (Pauly, Carlson, \& Perkin, 2012). Further to this, participants in this study emphasize that evaluation of program effectiveness is also necessary. Financial accountability of agencies was a particular concern expressed by participants in this study, one of whom indicated a need for further transparency on how finances are allocated:

There needs to be an outside quality assurance officer that comes in and pulls the records apart. An outside person that takes a look at the place, that does a 360 degree evaluation, talks to every staff person and to every resident, because a lot of stuff goes out the back door.

Similar to research evidence participants in this study indicated that knowledge and training of frontline staff, including training regarding specific populations (Freund \& Hawkins, 2004; Harris \& Katz, 2009), were key to improved service delivery. They suggested that education and awareness of the homeless experience would produce more relevant programming:

I think the ones who are high up in those buildings should actually go in and see the homeless. Eat a meal with them, sit down with them and actually talk to and walk with the homeless, and live it. I think they would get a better idea of what needs to change.

In contrast, some participants reported positive experiences with specific agencies or practitioners within agencies, noting that certain programs or practices by individual staff effectively increased their potential to exit homelessness. In particular, participants expressed the positive impact on a homeless person when staff, programs and agencies are able to effectively meet a specific need, or support unique circumstances or foster hope for an alternative future, as one respondent explained:

[One program] was so helpful in that sense that I didn't feel like I was being judged for being a working girl. I had all that help for all those years, which led me to want to straighten out. That's where I picked up the idea that I wanted a better life myself. I had that sense of belonging, people who came from where I had been, who wanted to help.

Research supports that dedicated staff and ongoing support from programs and agencies that serve people who are facing homelessness help them to transform their lives (Walsh, Ahosaari, Sellmer, \& Rutherford, 2010). This aligned with study participants' assertion that services were improved by demonstrations of compassion and care, and a focus on a person's unique circumstances. As one study participant offered:

I have a worker that comes to see me once a week, or whenever right, and we go over how I'm doing and how I'm doing with my plan - short-term and long-term goals. So for me, that's what working.

\subsubsection{Community accountability}

Canadians hold negative and inaccurate perceptions of individuals experiencing homelessness (Salvation Army, 2011). Discrimination directed at homeless people has been associated with decreased self-esteem and increased mental distress (Kidd, 2009). Participants in this study identified that societal stigma associated with being homeless is a significant barrier to exiting homelessness. One participant outlined, "the stated attitude and belief that the homeless are scum contributes to the cycle of homelessness".

Communities need to critically examine the structural barriers that foster societal stigma, compromise social safety nets, marginalize homeless people and minimize their ability to seek help (Shier, Jones, \& Graham, 2010). One study participant concurred with this, stating: 
It's not just about having a plan [referring to the 10 year plan to end homelessness]. We've got to change society. There's much bigger changes that need to happen. We need to get to a place where we care about our neighbours, and we're willing to live more simply, share more readily and give more generously.

\subsubsection{Government accountability}

In addition to using a housing first approach (Employment and Social Development Canada, 2013), and the financial incentives provided by the federal government to prevent or reduce homelessness (Human Resources and Skills Development Canada, 2012), participants articulated the need for housing and a living wage.

Co-researchers identified the need for policy reform regarding access to affordable housing. A significant decrease in funding for social housing (Federation of Canadian Municipalities, 2000) and additional access barriers occurred in 1996 as a consequence of the shift in social housing responsibilities from federal to provincial jurisdictions (Layton, 2008). Although the development of more housing options through financial incentives and tax measures has been made in Alberta (Alberta Secretariat for Action on Homelessness, 2008), the extensive wait lists for affordable housing (City of Calgary, 2013a), increasing rental rates and low vacancy rates (CMHC, 2012) suggests an urgent and increasing need for social housing.

The Wellesley Institute (2010) described the "precarious housing iceberg", outlining the 12 million households in Canada, 1.5 million of which are in 'core housing need'. They called for a national strategy to address affordable housing needs, for an evaluation of the effectiveness of current federal investment into affordable housing initiatives, and for the establishment of a coordinated plan to address the needs of all Canadians who are precariously housed. Further, the United Nations Human Rights Council (2009) reported that Canada is failing to meet its housing obligations, as the current affordable housing sector compromises the right to housing and adequate living standards.

Respondents in this study agreed with the need for government policy reform to support a livable or sustainable wage. Alberta's minimum wage is among the lowest in the country (Government of Alberta, 2013) and is deemed inadequate to meet basic needs and maintain a safe, decent, dignified standard of living (Vibrant Communities Calgary, 2013). Researchers have called for governments to commit to passing legislation that ensures that wages and income supports are at a living standard (Gaetz, 2010; Hulchanski, 2009). Increasing the minimum wage to a living wage has been advanced as an important poverty-reduction strategy (Battle, 2011; Cabal Garces, 2011; Goldberg \& Green, 1999), and increases an individual's capacity to exit poverty (Mackenzie \& Stanford, 2008). Living wages also enhance productivity among the workforce, decrease employment absenteeism and increase consumer purchasing power (Peterborough Social Planning Council and Trent Applied Social Research, 2004; Richards, Cohen, Klein, \& Littman, 2008).

Unlike most Canadian provinces (Canadian Federation of Apartment Associations, 2011), Alberta does not have a rent stabilization policy (Canadian Mortgage and Housing Corporation, 2013), which has been shown to reduce evictions (Early \& Olsen, 1998) and, in particular, decrease evictions into homelessness (Lapointe, 2004). The absence of rent stabilization policies, in conjunction with low vacancy rates, creates an 'affordability squeeze,' forcing low-income renters out of the market (Layton, 2008). The consequences of the affordability squeeze was described by one study participant:

You get a lot of people [moving to Calgary], because there are really good jobs, but with the high cost of living, you get all these slumlords, and the rents go up. So you're getting a one-bedroom for $\$ 600$, or a single bachelor suite, and not only is it not worth paying, it's not even worth living in, because it's all messy and has pest problems, and they're charging you an arm and a leg - and they get away with it.

While more research is required to fully understand the impact that rent stabilization policies have on homelessness, they have been shown to protect the poor, decrease turnover in rental housing while maintaining the opportunity for landlords to make profit (McFarlane, 2003).

\subsection{Themes 4: It's more than housing}

In addition to the housing first model, participants emphasized that members of the homeless community require case management. Case management is defined as a relationship-based service wherein a practitioner would assist with a variety of client-based services, including outreach, assessment and service planning, service linkage, monitoring of service delivery, and advocacy (Rubin, 1992). Study participants advanced that case management would reduce the 'warehousing' of the homeless population and increase people's capacity to exit homelessness by accommodating the unique circumstances and diversity within the homeless community. One respondent clarified the role of case management: 
I think people are warehoused a lot. There should be more one-on-one, than dealing with everyone at once where nothing gets done. We are all different, totally different. There should be more counselling rather than just and shipping them off.

Recent reviews concluded that case management led to increased time spent in housing and housing satisfaction (Nelson, Aubry, \& Lafrance, 2007) and "improved housing stability, reduced substance use, and removed employment barriers for substance users" (de Vet et al., 2013, p. e13). Case management has shown to be particularly effective with homeless persons who have multiple challenges, particularly individuals with mental health and addictions, as it enhances the intrapersonal relationship between client and support worker, increases a client's ability to engage with treatment, reduces homelessness and increases general life satisfaction (Chinman, Rosenheck, \& Lam, 2000).

Comprehensive supports, tailored to meet individual needs and offered from a centralized location, were also recommended. As one participant elucidated, "the system doesn't take into account that people have different needs. They need a place to stay where they can get those things addressed and get support".

Specialized services were also recommended for homeless populations who struggle with mental illness and substance abuse. As one participant noted, "there needs to be more, more individual work on where the person is lacking or sickness, stabilize their health and then their issues before anything else is going to work out, right?"

Current estimates indicate that $20 \%$ to $86 \%$ of homeless people suffer from concurrent mental health and substance abuse disorders (Canadian Institute for Health Information, 2007); the deinstitutionalization of mental health services the lack of community supports is a major contributing factor in this relationship (City of Victoria, 2007). Homeless people who struggle with their mental health are at a higher risk for general ill-health than others in the homeless population as they are more likely to engage in unhealthy behaviour including going without food, refraining from sleep, prostitution, abuse and violence (Nelson, Aubry, \& Lafrance, (2007). The often dire situation of homeless individuals with mental health concerns and addictions are outlined by one participant: I should have been dead so many times. It finally clicked in when one of the workers from the Ispecific outreach team] came to pick me up from the hospital and took me back to the [specific shelter]. [This time] I started using the services that they offered for housing, mental health, trauma and addictions. I'm surprised that I've been in detox this long, like 40 days. I got some goals set for housing, going back to school to [specific college], and they're helping me with that too. They're there helping and encouraging me.

Co-researchers expressed a need for centralized services that provide diverse forms of assistance as well as better interagency communication and collaboration. As one individual commented, these improvements would lead to more effective service provision:

Everybody who is homeless would be under the same umbrella, the rules would be consistent; everybody knows what's going on across the board. Under that umbrella, I would have medical care, dentistry, and mental health services right there available for people. It would be ideal if it could be just in one big location, or maybe throughout the city at different locations, but not operating under different names and with no communication; there needs to be more communication within the systems.

Centralized assistance, defined as an intake service that functions as a single point of entry to the community's wide array of services for homeless populations, reduces the extent to which homeless individuals have to independently navigate the complex maze of services offered (Basi, Clelland, Khind, Morris, \& Severinson, 2012). The benefits of centralized services are numerous and realized across client, agency and policy maker domains (Gardner, Ochoa, Alspaugh \& Mathews, 2010).

\subsection{Theme 5: Criminalization of homelessness}

Participants identified that homelessness is increasingly criminalized. The criminalization of homelessness perpetuates public perceptions that blame homeless people for their lack of housing and views them as delinquent, predatory and unsafe (O'Grady, Gaetz, \& Buccieri, 2011). Ultimately, this process has negative consequences on those who are trying to exit homelessness by heightening their experiences of social exclusion, reinforcing the association between homelessness and criminal behaviour, and distancing homeless populations from the support structures that can address the root causes of homelessness (Foscarinis, Cunnigham-Bowers, \& Brown, 1999; O'Grady et al., 2011). 
Police targeting, was noted by study participants, and, as one participant explained, resulted in the criminalization of homelessness:

There seems to be a double standard in society especially here in Calgary, where if you're contributing, wear a suit, look the part, [the police] overlook you. But if you have a backpack or you look out of sorts, they're right on you.

According to study participants, police targeting is promoted by the enactment of bylaws that specifically center on activities related to homelessness including panhandling and sleeping outdoors (The City of Calgary, 2013b), with bylaw enforcement functioning as a revolving door between homelessness and the criminal justice system. One responded noted:

If you are homeless and you have a pup tent and the [specific shelter] has kicked you out and you set up your tent somewhere along the river so you have a place to sleep, what the fuck is the point of giving you a trespassing ticket or a camping ticket or a loitering ticket? The purpose of that is so the cops can get you off the street and put you in prison, and they just don't have to deal with you. You can't pay it off while you're in jail, and then you get a warrant so you can't access services.

Several key mechanisms criminalize homeless populations, including: laws that prohibit activities related to homelessness, disproportionate law-enforcement activities against homeless people, the manipulation of physical environments to restrict usage by homeless populations, increased surveillance and policing in public spaces and increased incarceration of those who are homeless (O'Grady, Gaetz, \& Buccieri, 2011). Researchers noted that the six million dollars that was spent to enact the Safe City Initiative to crack-down on crime in Los Angeles, resulted in 201 arrests, mainly for jaywalking and loitering, which could have provided supportive housing for approximately 225 people (National Law Center on Homelessness and Poverty \& National Coalition for the Homeless, 2009). Further, the "get-tough" anti-homeless laws violate fundamental rights of homeless people (Foscarinis et al., 1999).

The criminalization of homelessness was further noted by participants, who critiqued the lack of support services offered to homeless populations who are released from prison. One participant illustrated the practice of discharging people from prison into homelessness:

It's not like when you're released from jail that they tell you what services are available, or how to access them. They don't give you the Street Survival Guide so that you can access this service and that service. They don't even tell you that they are supposed to give you warm clothing.

A lack of support services and employment opportunities following a period of incarceration negatively affects reintegration (Lynch \& Sabol, 2001). Additional supportive discharge procedures in prisons could decrease homelessness, increase employment, decrease the rate of recidivism and increase health (Gaetz \& O'Grady, 2009). Access to housing is a primary factor in successful discharge and reintegration (Bradley, Oliver, Richardson \& Slayter, 2001; Springer, Mars \& Dennison, 1998).

\subsection{Theme 6: Resilience in the face of adversity}

Resilience defined as a process of "continuing growth and articulation of capacities, knowledge, insight and virtues derived through meeting the demands and challenges of one's world" (Saleebey, 2006, p. 13). Participants in this study suggested several ways in which members of the homeless community exhibit resilience including community building and advocating for change.

Peer-to-peer support and empowerment were the cornerstones of community building and survival. Participants spoke of their ability to share information and resources, and to work together to navigate the system through extensive informal support networks. Forming a community with others who are homeless was a key strength, as one study member illustrated:

You don't know the different resources that are available until you get together with a group of people that are homeless. You learn more from them and you don't even need a cell-phone. We can just talk to each other.

An identified strength of the homeless community, according to study participants, is their function as allies and advocates in aiding others in accessing supports. One participant provided the following example:

Because I got a place of my own, I like to help others find their own home. I give out I community worker's name] because he helped me. I give his number to whoever I meet and they're like "Do you have a number?" 
I say, "Well, certainly," because I have the number memorized. I give it out to so many different people. I enjoy helping others because I've been helped myself.

For some participants, the hope of helping others, or being a voice for change, has become the incentive to overcome their own struggles and to persevere. As one participant noted: "I got to get strong to help others".

Resiliency was also demonstrated in the participants' capacities to share their stories, uncovering common experiences, as a means to affect change. Some expressed the desire to work for change in order to alleviate the suffering of those who may face similar problems in the future. One participant eloquently shared:

We definitely want to be able to share some of that experience... to use what we have to educate, to make the next person's journey easier. Whether or not she's homeless we still want her to be able to access services and get into housing. It might not be an easy thing, but we want it to be easier for her than it was for us. We want people to realize that we did not wake up and decide we wanted to be criminals and we didn't grow up thinking we were going to be junkies and hookers. We had dreams just like everybody else when we were little girls. This is not what I had planned for my life, but you might as well own the experience and do it with some dignity. We've learned a lot as women and we've become a really good support for each other.

In calling for wider accountability, one community researcher eloquently articulates the phenomenon of resiliency in the face of adversity:

I am not data, a number, a unit of livestock or a child. Please treat me as the human being I am, and if you agree to help me, please help me with what I really need, not with what you think I need, the minimum you think I deserve, or the things you were going to throw away, anyway - as I can only make use of garbage for so long. I will not shoulder the responsibility of manufacturing gratitude for second hand efforts and objects if I am neglected and deteriorate further. I' $m$ tapped and traumatized by helping systems that rarely truly help, and I'm so very, very tired.

\subsection{Limitations of the study}

In order to limit the number of demographic questions and invasiveness of the study, the researchers did not inquire about the participants' family status, parental status, number of children, or whether they were currently in an intimate partnership. Thus, the study could not comment on how experiences of homelessness, services, and service barriers may impact family life among homeless persons. Gaining a better understanding of these issues can create the necessary foundation knowledge to develop policies and tailor services for homeless families. This is a consideration for future research.

An important objective of this research was to open the space for many diverse voices, views and experiences of persons with a history of homelessness. Unfortunately, while the research team was involved in planning three final focus groups in partnership with diverse groups including: the disability community; the lesbian, gay, bisexual, transgendered, and queer (LGBTQ) community; and the immigrant/refugee community, the study was put on hold. This occurred because the community partner was dissolved during the research study, the funding stopped, and thus data gathering process was terminated prematurely. These planned focus groups did not take place and therefore the voices of these communities may not be adequately represented in this report. Among the negative impacts of these changes was a time-gap in the project, which sparked levels of distrust among some members of the homeless community. The researchers did secure additional funding and were able to complete the objectives of the project with continued engagement of persons with lived experience of homelessness in the data analysis, interpretation and dissemination phases of the research.

\subsection{Discussion and recommendations}

Findings from the Community Voices study demonstrates that people who are homeless experience oppression within individual, cultural and structural domains. This draws attention to the need for an anti-oppressive approach and social justice principles embedded within institutional operations and policies designed to address homelessness. A minimum standard to meet this objective includes agency-funded and supported training in antioppressive practices for all agency staff and volunteers as a core element of ongoing professional development. Training should incorporate social justice principles and include the involvement of persons with experiences of homelessness.

The increasing criminalization of homeless populations is an exemplar of oppressive practices, as it further marginalizes and stigmatizes those who are experiencing homelessness, and reduces their ability to create and 
implement an exit plan. While anti-oppressive training within policing and justice systems is critical, the need to assess and eliminate laws, which contribute to the cycle of homelessness is paramount.

On a broader level, increasing the public's understanding, empathy and awareness of the barriers faced by those experiencing homelessness is needed. This could be addressed, in part, by a broad social media campaign, which incorporates a human rights and social justice framework, with an emphasis on identifying and addressing the structural contributors of homelessness.

The entrenchment of homelessness in Canada calls for greater accountability on all three government levels, within homeless serving agencies, and among the general public. Voters need to hold governments accountable for protecting vulnerable and oppressed citizens, and the federal government should support provinces and municipalities with adequate funding to ensure that appropriate supports can be developed and maintained (Gaetz, 2012; Layton, 2008).

A considerable body of research indicates that a core need for homeless people is stable housing (Bradley, Oliver, Richardson, \& Slayter 2001; Early \& Olsen, 1998; Nelson, Aubry \& Lafrance, 2007). While temporary shelters do not provide a solution to homelessness, they must nevertheless offer a safe and dignified experiences for guests. To this end, improvements in sanitation, sleeping conditions and access to training, workshops, computers and Internet are suggested.

Affordable and inclusionary housing is necessary step to address the pervasive issue of homelessness. Rent control policies to protect low-wage earners in the rental market are one method of achieving this end. However, as indicated in this study and supporting literature (Gaetz, Scott \& Gulliver, 2013), "it is more than just housing". As indicated in this study, people who are homeless may experience complex issues and require comprehensive and individualized services. Further, individuals should not be discharged into homelessness from correctional services, foster care, hospitals or other programs. Appropriate resources and transitional case management should replace these unacceptable practices.

Access to employment for members of the homeless community is necessary to sustain a decent quality of life. Significant barriers to employment are experienced by homeless people and have serious negative consequences on their quality of life and their ability to fully realize the rights of citizenship. The provision of humanizing and dignified employment opportunities is not only ethically imperative but justified from political and economic standpoints. However, as evidenced by the high rate of employment among the Calgary's homeless population, employment without affordable accommodation and proper supports will create a solution to homelessness. Due to high housing costs, a minimum wage, which reflects a living wage, is necessary. Without such protective policies, low-income earners will still face the threat of homelessness.

The United Nations (1948, Article 24) identifies housing as basic human right. A critical step to addressing the root causes of homelessness and also assisting those who are currently homeless is adopting a human rights framework in housing policies and programs, including the 10 Year Plan to End Homelessness. On a broader scale, tangible actions are needed by the Canadian government in order to engender national accountability for Article 24. This would include the enactment a national housing strategy so that all Canadians can access their right to shelter. All levels of government must work together to support and expand existing initiatives that lead to safe, affordable housing options.

\section{References}

Alberta Secretariat for Action on Homelessness (2008). A plan for Alberta. Ending homelessness in 10 years. Retrieved from http://alberta.ca/albertacode/images/AlbertaPlantoEndHomelessness.pdf

Alberta Secretariat for Action on Homelessness. (2011). 2010- 11 Report to the Minister: Progress report on the implementation of a plan for Alberta: Retrieved from: http://humanservices.alberta.ca/documents/Annual_report_to_Minister_2010-11.pdf

Altpeter, M., Schopler, J. H., Galinsky, M. J., \& Pennell, J. (1999). Participatory research as social work practice: When is it viable? Journal of Progressive Human Services, 10(2), 31-53. doi:10.1300/J059v10n02_04 http://dx.doi.org/10.1300/J059v10n02_04

Atkinson, R., \& Flint, J. 2004. Snowball sampling. In The SAGE encyclopedia of social science research methods, ed. M. S. Lewis-Beck, A. Bryman and T. Futing Liao 1044-1045. Thousand Oaks: Sage Publications. http://dx.doi.org/10.4135/9781412950589 
Basi, S., Clelland, T., Khind, N., Morris, A., \& Severinson, P., (2012). Housing homeless youth in Vancouver: Key barriers and strategic responses. British Columbia Housing Corporation. Retrieved from http://www.homelesshub.ca/ResourceFiles/BCP\%20BC\%20 Housing\%20Presentation.pdf

Battle, K. (2011). Restoring minimum wage in Canada. Caledon Institute of Social Policy. Retrieved from http://www.caledoninst.org/publications/pdf/931eng.pdf

Begin, P., Casavant, L., Miller Chenier, N., \& Dupuis, J. (1999). Homelessness. (Government Report No. PRB 99 1E). Ottawa, Ontario: Library of Parliament.

Bishop, A. (2002). Becoming an ally: Breaking the cycle of oppression in people. (2nd ed.). Halifax: Fernwood Publishing Company.

Blankertz, L., McKay, C., \& Robinson, S. (1998). Work as a rehabilitative tool for individuals with dual diagnosis. Journal of Vocational Rehabilitation, 11, 113-123. http://dx.doi.org/10.1016/S1052-2263(98)00042-7

Bradley, K., Oliver, M., Richardson, N., \& Slayter, E. 2001. No place like home: Housing and the ex-prisoner. Community Resources for Justice, 1-12. Retrieved from http://b.3cdn.net/crjustice/a5b5d8fa98ed957505_hqm6b5qp2.pdf

Boylorn, R. (2008). Participants as co-researchers. In Lisa M. Given (Ed.), The SAGE Encyclopedia of Qualitative Research Methods. (pp. 600-602). Thousand Oaks, CA: SAGE Publications, Inc. http://dx.doi.org/10.4135/9781412963909.n310

Brydon-Miller, M. (1997). Participatory action research: Psychology and social change. Journal of Social Issues, doi:10.1111/0022-4537.0004

Bryman, A. \& Burgess, R. (1993). Analysing qualitative data. London: Routledge

Cabal Garces, M. (2011, June). Living wage: An introduction. Retrieved from www.gwpoverty.ca

Calgary Homeless Foundation. (2014). Abberta point in time count October 2014. Retrieved from http://www.cbc.ca/news/canada/calgary/homelessness-count-for-alberta-reveals-most-live-in-calgary-1.2844876

Calgary Homeless Foundation (2012a) Calgary Homeless Foundation Annual Report, 2012. Retrieved from http://calgaryhomeless.com/assets/Progress/Year4/CHF2012AnnualReport.pdf

Calgary Homeless Foundation. (2012b). Sustainable supports for adult males: Effective employment models to end homelessness. Retrieved from http://calgaryhomeless.com/assets/research/Employment-ModelsReport.pdf

Canadian Federation of Apartment Associations. (2011). Rent control across Canada. Retrieved from: http://realestateforums.com/caic/docs/2011PPT/John_Dickie.pdf

Canadian Homelessness Research Network (2012) Canadian definition of homelessness. Homeless Hub. Retrieved from www.homelesshub.ca/CHRNhomelessdefinition/

Canadian Housing and Mortgage Corporation. (2013). Renting in Alberta. Retrieved from

Canadian Institute for Health Information. (2007). Improving the health of Canadians: Mental health and homelessness report. Canadian Population Health Initiative. Retrieved from https://secure.cihi.ca/free_products/mental_health_report_aug22_2007_f.pdf

Chinman, M. J., Rosenheck, R., \& Lam, J. A. (2000). The case management relationship and outcomes of homeless persons with serious mental illness. Psychiatric Services, 51(9), 1142-1147. doi: 10.1176/appi.ps.51.9.1142

Chiu, L. F. (2008). Engaging communities in health intervention research/practice. Critical Public Health, 18(2), 151-159. doi:10.1080/09581590701771725

City of Calgary. (2008). 2008 Biennial Count of Homeless Persons. Retrieved from http://www.calgary.ca/portal/server.pt/gateway/PTARGS_0_2_428286_0_0_18/Biennial+Count+of+Hom eless+Persons.htm

City of Calgary. (2013a). Waiting list for housing. Retrieved from: http://www.calgary.ca/CS/OLSH/Pages/Calgary-Housing-Company/Applicant\%20information/Waitinglist-for-housing.aspx

City of Calgary. (2013b). Bylaws. Retrieved from http://www.calgary.ca/CA/cityclerks/Pages /Legislativeservices/Bylaws.aspx

City of Victoria. (2007). Mayor's Task Force on Breaking the Cycle of Mental Illness, Addictions and Homelessness: Report of the Expert $\quad$ Panel. http://www.victoria.ca/assets/City Hall/Documents/tskfrc_brcycl_exprtp.pdf

De Vet, R., van Luijtelaar, M. J., Brilleslijper-Kater, S. N., Vanderplasschen, W., Beijersbergen, M. D., \& Wolf, J. R. (2013). Effectiveness of case management for homeless persons: A systematic review. American Journal of Public Health, 103(10), e13-26. http://dx.doi.org/10.2105/AJPH.2013.301491

Early, D. W., \& Olsen, E. O. (1998). Rent control and homelessness. Regional Science and Urban Economics, 28(6), 797-816. http://dx.doi.org/10.1016/S0166-0462(98)00034-9

Employment and Social Development Canada (2013). Terms and conditions Homelessness Partnering Strategy. Retrieved from http://www.hrsdc.gc.ca/eng/communities/homelessness/funding/terms.shtml

Eyrich-Garg, K. M. (2011). Sheltered in cyberspace? Computer use among the unsheltered 'street' homeless. Computers in Human Behavior, 27(1), 296-303. http://dx.doi.org/10.1016/j.chb.2010.08.007 
Ferguson, K. Bender, K. Thompson, S., Maccio, E., \& Pollio, D. (2011). Employment status and income generation among homeless young adults: Results from a five-city, mixed-methods study. Youth \& Society, 44(3), 385407. http://dx.doi.org/10.1177/0044118X11402851

Federation of Canadian Municipalities. (2000). Toward a national housing strategy for Canada: FCM working paper. Retrieved from http://action.web.ca/home/housing/resources.shtml?x=67139\&AA_EX_Session=978a9c885bc3f70b6050 7f913d440843

Fook J. \& Askeland G. A. (2007). Challenges of critical reflection: 'Nothing ventured, nothing gained'. Social Work Education, 26(5), 520-523. http://dx.doi.org/10.1080/02615470601118662

Foscarinis, M., Cunningham-Bowers, K., \& Brown, K. E. (1999). Out of sight - out of mind? The continuing trend toward the criminalization of homelessness. Georgetown Journal on Poverty Law \& Policy, 6(2), 145-164.

Freund, P. D., \& Hawkins, D. W. (2004). What street people reported about service access and drug treatment. Journal of Health \& Social Policy, 18(3), 87-93. http://dx.doi.org/10.1300/J045v18n03_05

Gaetz, S. (2012). The real cost of homelessness. Can we save money by doing the right thing? Toronto: Canadian Homeless Research Network Press. Retrieved from http://www.homelesshub.ca/ResourceFiles/costofhomelessness_paper21092012.pdf

Gaetz, S. (2010). The struggle to end homelessness in Canada: How we created a crisis, and how we can end it. The Open Health Services and Policy Journal, 3, 21-26. Retrieved from http://www.homelesshub.ca/Library/Editorial-The-Struggle-to-End-Homelessness-in-Canada-How-We-Created-theCrisis-and-How-We-Can-End-it---Free-Access-48220.aspx http://dx.doi.org/10.2174/1874924001003020021

Gaetz, S. \& O'Grady, B. (2009). Homelessness, incarceration, and the challenge of effective discharge planning: A Canadian case. Cities Centre \& University of Toronto. Retrieved from http://www.homelesshub.ca/ResourceFiles/Documents/7.3\%20Gaetz\%20and\%200\%27Grady\%20\%20Homelessness\%20\%20and\%20Discharge\%20Planning.pdf

Gaetz, S., Scott, F., \& Gulliver, T. (Eds.) (2013). Housing first in Canada: Supporting communities to end homelessness. Toronto: Canadian Homelessness Research Network Press. http://dx.doi.org/10.1080/02673037.2013.767884

Gardner, T. Ochoa, J. Aspaugh, M., \& Mathews, N. (2010). Centralized intake for helping people experiencing homelessness: Overview, community profiles, and resources. The Cloudburst Group; U.S. Department of Housing and Urban $\quad$ Development. Retrieved from http://www.homelesshub.ca/Resource/Frame.aspx?url=https\%3a\%2f\%2fwww.onecpd.info\%2fresources $\% 2$ fdocuments\%2fHPRP_CentralizedIntake.pdf\&id=54801\&title=Centralized+Intake+for+Helping+Peop le+Experiencing+Homelessness $\% 3 a+0 v e r v i e w \% 2 c+$ Community+Profiles\%2c+and+Resources\&owner $=121$

Goldberg, M. \& Green, D. (1999). Raising the floor. The social and economic benefits of minimum wages in Canada. Ottawa: Canadian Centre for Policy Alternatives. Retrieved from http://www.policyalternatives.ca/sites/default/files/uploads/publications/BC_Office_Pubs/raising_floor.pdf

Government of Alberta (2013). Alberta minimum wage profile: April 2012- Mar 2013. Retrieved from: http://eae.alberta.ca/media/374692/final\%20alberta\%20minimim\%20wage\%20profile\%2020122013\%20with\%20cover\%20page.pdf

Government of Alberta (2013, February) Alberta's Social Policy Framework. Retrieved from http://socialpolicyframework.alberta.ca/files/documents/ahs-nonannotatedfrmwrk-webfinal.pdf

Gulcur, L., Stefancic, A., Shinn, M., Tsemberis, S., \& Fischer, S. N. (2003). Housing, hospitalization and cost outcomes for homeless individuals with psychiatric disabilities participating in continuum of care and housing first programs. Journal of Community and Applied Psychology, 13, 171-186. DOI 101002/casp.723.

Harding, J. (2013). Qualitative data analysis from start to finish. London: SAGE Publishers

Harris, B., \& Katz, R. (2009). You can't really call this home: Perspectives on service delivery from Salvation Army shelter users and service providers. Salvation Army of Canada. Retrieved http://www.homelesshub.ca/Resource/Frame.aspx?url=http\%3a\%2f\%2fwww.homelesshub.ca\%2fResou rceFiles\%2ferrpoidw.pdf\&id=45582\&title=You+Can't+Really+Call+this+Home\%3a+Perspectives+on+ Service+Delivery+from+Salvation+Army+Shelter+Users+and+Service+Providers\&owner $=121$

Hulchanski, J. D. (February, 2009). Homelessness in Canada: Past, present, future. Conference keynote address. Growing Home: Housing and Homelessness in Canada. University of Calgary. Retrieved from http://www.cprn.org/documents/51110_EN.pdf

Human Resources and Skills Development Canada. (2012). The Homelessness Partnering Strategy: Partnerships that work. Retrieved from http://www.hrsdc.gc.ca/eng/success

James, C. Este, D. Thomas, W., Benjamin, A. Lloyd, B., \& Turner, T. (2010). Race \& well-being. The lives, hopes, and activism of African Canadians. Toronto, ON: Fernwood.

Kauppi, C., \& Bradley, S. (2003). Structural factors associated with homelessness. A review of the international literature. National Homelessness Initiative. Regional Research Fund. Retrieved from http://www.homelesshub.ca/ResourceFiles/Structural_Factor_associated_with_Homelessness_Review.pdf 
Kidd, S. (2009). Social stigma and homeless youth. In J. D. Hulchanski, P. Campsie, S. Chau, S. Hwang, \& E. Paradis, (eds.) Finding Home: Policy Options for Addressing Homelessness in Canada (ebook), University of Toronto. Retrieved from www.homelesshub.ca/FindingHome

Koirala-Azad, S. \& Fuentes, E. (2009-2010). Activist scholarship: Possibilities and constraints of participatory action research. Social Justice, 36(4), 1-5.

Krueger, R. A., \& Casey M. A. (2000). Focus groups: A practical guide for applied research. 3rd Edition. Thousand Oaks, CA: Sage Publications. http://dx.doi.org/10.1037/10518-189

Kydra, A. D., \& Compton, M. T. (2009). Mistrust of outreach workers and lack of confidence in available services among individuals who are chronically street homeless. Community Mental Health Journal, 45, $144-150$. http://dx.doi.org/10.1007/s10597-008-9163-6

Lam, J. \& Rosenheck, R. (2000). Correlates of improvement in quality of life among homeless persons with serious mental illness. Psychiatric Services, 51, 116-118. http://dx.doi.org/10.1176/ps.51.1.116

Lapointe L. (2004). Analysis of evictions under the tenant protection act in the city of Toronto and the non-profit housing sector. City of $\quad$ Toronto. $\quad$ Retrieved from http://www.homelesshub.ca/Resource/Frame.aspx?url=http\%3a\%2f\%2fwww.toronto.ca\%2fhousing\%2f pdf\%2fevictions_nonprofithousingsector.pdf\&id=36152\&title=Analysis +of+Evictions+Under+Teh+Tena $\mathrm{nt}+$ Protection+Act+in+the+City+of+Toronto+the+Non-Profit+Housing+Sector\&owner $=121$

Layton J. (2008). Homelessness: How to end the national crises. Penguin: Toronto.

Lynch, P. J. \& Sabol, W. J. (2001). Prisoner reentry in perspective. Crime Policy Report, 3, 1-24.

Macdonald, C. (2012). Understanding participatory action research: A qualitative research methodology option. Canadian Journal of Action Research, 13(2), 34-50.

Mackenzie, H. \& Stanford, J. (2008). A living wage for Toronto. Retrieved from http://www.policyalternatives.ca/sites/default/files/uploads/publications/Ontario_Office_Pubs/2008/A_ Living_Wage_for_Toronto.pdf

McFarlane, A. (2003). Rent stabilization and the long-run supply of housing. Regional Science and Urban Economics, 33(3), 305-333. http://dx.doi.org/10.1016/S0166-0462(02)00031-5

Mullaly, B. (2010). Challenging oppression and confronting privilege. (2nd ed.). Toronto: Oxford University Press.

Munoz, J. P., Reichenbach, D., \& Hansen, A. M. W. (2005). Project employ: Engineering hope and breaking down barriers to homelessness. Work, 25(3), 241-252.

National Law Center on Homelessness \& Poverty \& National Coalition for the Homeless. (2009). Homes not handcuffs: The criminalization of homelessness in U.S. cities. Retrieved from http://www.homelesshub.ca/Resource/Frame.aspx?url=http\%3a\%2f\%2fwww.nlchp.org\%2fcontent $\% 2 \mathrm{fp}$ ubs\%2f2009HomesNotHandcuffs2.pdf\&id=45968\&title=Homes+Not+Handcuffs\%3a+The+Criminalizati on+of+Homelessness+in+US+Cities\&owner $=48$.

Nelson, G., Aubry, T., \& Lafrance, A. (2007). A review of the literature on the effectiveness of housing and support, assertive community treatment, and intensive case management interventions for persons with mental illness who have been homeless. American Journal of Orthopsychiatry, 77(3), 350-361. http://dx.doi.org/10.1037/0002-9432.77.3.350

O'Grady, B., Gaetz, S., \& Buccieri, K. (2011). Can I see Your ID? The policing of youth homelessness in Toronto. Justice for Children \& Youth, and Homeless Hub Press. Retrieved from http://www.homelesshub.ca/ResourceFiles/CanISeeYourID_nov9.pdf

Pauly, B., Carlson, E., \& Perkin, K. (2012). Strategies to end homelessness: Current approaches to evaluation. Toronto: Canadian Homelessness Research Network Press.

Parkland Institute. (January 28, 2013). Alberta is Canada's most unequal province and Calgary the most unequal city. Retrieved from http://parklandinstitute.ca/media/comments/alberta_is_canadas_most_unequal_province

Patton, M. Q. (2002). Qualitative research \& evaluation methods. (3rd ed.) Newbury Park, London: Sage Publications

Peressini, T. L., Hulchanski, J. D., McDonald, L., \& Canada Mortgage and Housing Corporation. (1996). Estimating homelessness: Towards a methodology for counting the homeless in Canada: Background report. Ottawa: The Division.

Richards, T., Cohen, M., Klein, S., \& Littman, D. (2008). Working for a living wage. Making paid work meet basic family needs in Vancouver and Victoria. Retrieved from http://www.policyalternatives.ca/sites/default/files/uploads/publications/BC_Office_Pubs/bc_2008/ccpa _bc_living_wage_2008.pdf

Rubin, A. (1992). Is case management effective for people with serious mental illness? A research review. Health \& Social Work, 17(2), 238.

Saleebey, D. (2006). The strengths perspective in social work practice (4th ed.). Boston, MA: Pearson Education.

Salvation Army. (2011). Canada speaks: Exposing persistent myths about the 150,000 Canadians living on the street. Retrieved from http://www.salvationarmy.ca/DPresources/CanadaSpeaks_report_May2011.pdf

Shenton, A. K, (2004). Strategies for ensuring trustworthiness in qualitative research projects. Education for Information, 22, 63-75. 
Shier, M. L., Jones, M. E., \& Graham, J. R. (2010). Perspectives of employed people experiencing homelessness of self and being homeless: Challenging socially constructed perceptions and stereotypes. Journal of Sociology \& Social Welfare, XXXVII(4), 13-37.

Shier, M. L., Jones, M. E., \& Graham, J. R. (2012). Employment difficulties experienced by employed homeless people: Labor market factors that contribute to and maintain homelessness. Journal of Poverty, 16(1), 2747. http://dx.doi.org/10.1080/10875549.2012.640522

Sommers. J. Buchwitz, R., Krawczyk, M., Dowler, M., Edwards, M., Berti, M. . . Goulding, R. (2005). Lifting roadblocks: Identifying barriers to employment for homeless people and practical tool for removing those barriers. Strathcona Research Group. Retrieved from http://www.dtes.ca/pathways/liftingroadblocks.pdf

Springer, J., Mars, J., \& Dennison, M. (1998). Breaking the cycle of homelessness: Interim report of the Mayor's Homelessness Action Task Force. City of Toronto. Retrieved from http://www.homelesshub.ca/Library/AProfile-of-the-Toronto-Homeless-Population-35168.aspx

Statistics Canada. (2013). Labour force characteristics, seasonally adjusted, by census metropolitan area: 3 month moving average. Retrieved from http://www.statcan.gc.ca/tables-tableaux/sum-som/101/cst01/lfss03keng.htm

Strauss, A. \& Corbin, J. (1990). Basics of qualitative research: Grounded theory procedures and techniques. Newbury Park, CA: Sage Publications, Inc.

Stuart, H., \& Arboleda-Florez, J. (2000). Homeless shelter users in the post deinstitutionalized era. Canadian Journal of Psychiatry, 45, 55-62.

Suttor, G. (2009). Rental paths from postwar to present: Canada compared. Cities Centre. University of Toronto.

Thompson, S.J., McManus, H., Lantry, J., Windsor, L., \& Flynn, P. (2006). Insights from the street: Perceptions of services and providers by homeless young adults. Evaluation and Program Planning, 29, 34-43. http://dx.doi.org/10.1016/j.evalprogplan.2005.09.001

Trypuc, B., \& Robinson, J. (2009). Homeless in Canada. Charity Intelligence Canada. Retrieved from www.charityintelligence.ca

Tsemberis, S., Moran, L., Shinn, M., Asmussen, S., \& Shern, D. (2003). Consumer preference programs for individuals who are homeless and have psychiatric disabilities: A drop-in center and a supported housing program. American Journal of Community Psychology, 32(3-4), 305-317. http://dx.doi.org/10.1023/B:AJCP.0000004750.66957.bf

United Nations Human Rights Council (February, 2009). Promotion and protection of all human rights, civil, political, economic, social and cultural rights, including the right to development. Report of the Special Rapporteur on adequate housing as a component on the right to an adequate standard of living, and o the right to non-discrimination on this context- Miloon Kothari. Retrieved from http://www.ligi.ubc.ca/sites/liu/files/Publications/2009_Nov26_KothariRTH_Canada07.pdf

Vibrant Communities Calgary (2013). Living wage basics. Retrieved from http://www.vibrantcalgary.com/vibrant-initiatives/living-wage/living-wage-basics/

Walsh, C. A., Ahosaari, K., Sellmer, S., \& Rutherford, G. E. (2010). Making meaning together: An exploratory study of therapeutic conversation between helping professionals and homeless shelter residents. The Qualitative Report, 15(4), 932-947

Wellesley Institute (2010). Precarious housing in Canada. Retrieved from http://www.wellesleyinstitute.com/wp-

Williams, M., Unrau, Y., \& Grinnell, R. M. (1998). Introduction to social work research. Illinois: F.E. Peacock Publishers. http://dx.doi.org/10.1093/swr/22.1.3 